\title{
Clinical features of ESBL-producing E. coli responsible for bloodstream infections in French patients and molecular characterization of isolates
}

\author{
A Gaultier ${ }^{1}$, N Girard ${ }^{2,3}$, X Bertrand ${ }^{4}$, R Quentin ${ }^{5}$, NL Van Der Mee-Marquet ${ }^{6^{*}}$ \\ From 3rd International Conference on Prevention and Infection Control (ICPIC 2015) \\ Geneva, Switzerland. 16-19 June 2015
}

\section{Introduction}

We conducted an annually bloodstream infection (BSI) survey into hospitals overlapping the Centre France region (2.6 million). Since 2005, the incidence of BSIs associated with ESBL-producing E. coli (ESBLEc) increased.

\section{Objectives}

To improve the understanding of the pathway and the determination of the risk factors of ESBLEc-BSIs.

\section{Methods}

For each BSI, were reported patient age, sex, recent hospitalization, living in nursing home, recent antibiotherapy, urinary catheterization, BSI source, death within 7days of diagnosis.

BSI isolates were studied: antimicrobial susceptibility, determination of molecular mechanism associated with ESBL-production, genetic diversity of ESBLEc (MLST).

\section{Results}

During the survey (474,953 PDs), 443 E. coli BSI were identified, including 31 ESBLEc (7.0\%; 30/31 CTX-M). Incidence of community acquired(CA)- and healthcare associated(HCA)-BSI were $0.47 / 100,000$ and $0.040 / 1,000$ PDs, respectively.

\section{Major findings}

For ESBLEc-CA-BSIs, male/female ratio was 1.4, median age 80 , urinary BSI source in $50 \%$ of cases, recent antibiotherapy in $33 \%$. Most ESBLEc were resistant to fluoroquinolones (67\%), SXT/TMP (67\%). High genetic diversity (8 STs including 4 ST131).
For ESBLEc-HCA-BSI, male/female ratio was 0.9, median age 75 , urinary BSI source in $63 \%$ of cases (recent catheterization in 1/2), recent antibiotherapy in $58 \%$. Most ESBLEC were resistant to fluoroquinolones (79\%), SXT/TMP (63\%). Low genetic diversity (9 STs including 7 ST131).

Among BSI, ESBLEc-BSI were associated with healthcare $(\mathrm{p}=0.004)$, long-stay unit $(\mathrm{p}=0.018)$, recent antibiotherapy $(\mathrm{p}=0.002)$. ESBLEc were associated with resistance to fluoroquinolones, SXT/TMP and genta./ tobramycine $(\mathrm{p}<0.001)$.

Among ESBLEc-BSI, clinical determinants and BSI characteristics similar whatever the clonal group excepted for ST131 associated with long-stay unit $(\mathrm{p}=0.042)$.

Among ST131-BSI, clinical determinants and BSI characteristics similar for ESBLEc and non ESBLEc excepted median age higher in ESBLEc (80/67).

\section{Conclusion}

Recent antibiotherapy (and easy spread into long-stay units for ST131): likely the major risk factor for ESBLEc BSI.

\section{Disclosure of interest}

None declared.

\section{Authors' details}

${ }^{1}$ Département de Bacteriologie et Hygiène, France. ${ }^{2}$ Centre Hospitalier Universitaire de Tours, Tours, France. ${ }^{3} \mathrm{RHC}$-arlin, Besançon, France. ${ }^{4}$ Service d'hygiène, Centre Hospitalier Universitaire de Besançon, Besançon, France. ${ }^{5}$ Service de Bactériologie et Hygiène, Centre Hospitalier Universitaire de Tours, Tours, France. 'Departement de Bactériologie et Hygiène, Réseau des hygiénistes du Centre, Centre Hospitalier Universitaire de Tours, Tours, France. 
doi:10.1186/2047-2994-4-S1-P125

Cite this article as: Gaultier et al:: Clinical features of ESBL-producing E. coli responsible for bloodstream infections in French patients and

molecular characterization of isolates. Antimicrobial Resistance and Infection Control 2015 4(Suppl 1):P125.

Submit your next manuscript to BioMed Central and take full advantage of:

- Convenient online submission

- Thorough peer review

- No space constraints or color figure charges

- Immediate publication on acceptance

- Inclusion in PubMed, CAS, Scopus and Google Scholar

- Research which is freely available for redistribution 